Apidologie, 1980, 11 (3), 209-215.

\title{
THE PHYSICAL CHARACTERISTICS OF ARTIFICIAL PROTEIN DIETS FOR HONEYBEES (APIS MELLIFERA) II
}

\author{
Keith M. DOULL (1), T. W. HANCOCK (2) and L. N. STANDIFER (3)
}

\section{SUMMARY}

The physical characteristics of artificial protein diets based on Torula-Yeast, in which sucrose provided the carbohydrate component have been studied. Mean consistencies and rates of hardening of the diets compared favourably with Brewer's Yeast-honey diets reported in the previous paper, but when glycerol or invertase were added the rates of hardening of the diets were reduced. It was found, however, that mould developed in the diets due to the presence of mould organisms in the Torula Yeast, which cannot therefore be recommended for use in artificial diets.

In a second experiment with diets based on spray-dried Brewer's Yeast, casein was added to improve the protein content of the diets. Mean consistencies of the diets were substantially higher that those of the diets in the first experiment but rates of hardening did not increase.

The significance of physical characteristics of artificial protein diets for honeybees is discussed.

\section{INTRODUCTION}

The first paper in this series (Doull et al., in press) reported the results of a study of the effects of a commercial High Fructose Corn Syrup on an artificial diet based on spray-dried Brewer's Yeast.

Since neither the corn syrup nor the Brewer's Yeast are readily available outside North America, the physical characteristics of diets containing Torula Yeast and sucrose have been examined.

These diets, along with those recommended by Doull (1977) and STANDIFER et al. (1978), had protein levels below the average for stored pollen (HERBERT et al. 1977)

(1) and (2) Honorary Visiting Research Fellow, Entomology Department, and Statistical Consultant respectively, Waite Agricultural Research Institute, the University of Adelaide, Glen Osmond, S.A.

(3) Centre Director/Research Leader, U.S.D.A., Carl Hayden Bee Research Centre, Tucson, Arizona 85719 , U.S.A. 
and below the minimum for colony response (KLEINSCHMIDT and KonDos 1976). A further test was therefore made of a diet to which casein had been added to provide more acceptable levels of crude protein.

\section{METHODS}

Methods were similar to those reported in the previous paper. The diets were tested in a constant environment room at $34.5^{\circ} \mathrm{C}$ and $55 \% \mathrm{R} . \mathrm{H}$. Consistencies of the test diets were measured with a Penetrometer and consistencies of the diets were calculated as " the force in grams $/ \mathrm{mm}^{2}$ to penetrate the sample ". Both experiments extended over a period of 17 days during which time Penetrometer readings were recorded eight times. Two treatments - covered and open -- were applied to the test diets and there were three samples of each diet in each treatment.

\section{Experiment 1}

Proportions of yeast and sucrose were those recommended by Doull (1977). Torula Yeast was used in all diets with sucrose as the sugar component of the diets. Dextrose, glycerol and invertase were added to some diets to observe their effects on the hygroscopic properties of the mixtures.

In the four formulae set out below the amounts of all ingredients are in grams :

\section{Experiment $I$}

\section{Diet 1}

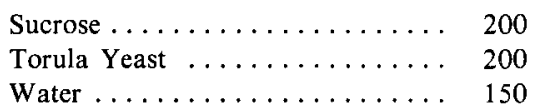

Diet 2

Sucrose ................. 200

Torula Yeast ............ 200

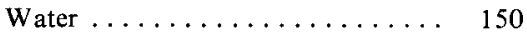

Invertase

For the first three diets the yeast and sucrose were mixed together and the water was then added to the dry mixture while for Diet 4 the sugars were dissolved in the boiling water. The resulting syrup was allowed to cool and was then mixed with the yeast, earlier experience having shown that the addition of hot syrup to yeast resulted in a very hard product. (Doull unpub.).

\section{Experiment 2}

\section{Diet 1}

Brewers Yeast

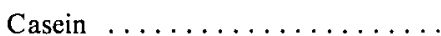

Sucrose ................. 150

Water ................ 150

Invertase $\ldots \ldots \ldots \ldots \ldots \ldots \ldots .1 .2$
Diet 3

Sucrose . . . . . . . . . . . . . 200

Torula Yeast ............ 200

Water ................ 150

Glycerol .............. 2

\section{Diet 4}

Sucrose ................. 190

Torula Yeast ............ 200

Water ............... 150

Dextrose ............... 10 
Experiment 2 (cont.)

Diet 3

Brewers Yeast $\ldots \ldots \ldots \ldots \ldots \ldots 270$

Casein .............. 30

“ Type 50 » syrup ........... 206

Water ................ 94
Diet 4

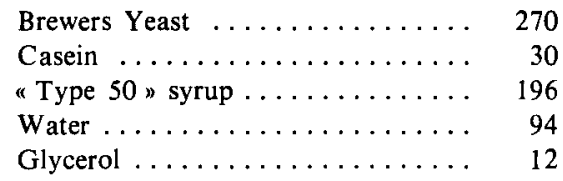

" Type 50 " syrup is a commercial enzyme-inverted sugar from U.S.A. It contains $77 \%$ total sugars with a $1: 1$ dextrose : laevulose ratio.

\section{RESULTS}

The results of the two experiments are presented in Tables 1 and 2 below. As was the case in the experiment reported in the earlier paper, mean consistencies and rates of hardening of the diets in the open treatments were substantially higher than those of the same diets in the covered treatments in both experiments.

Accordingly, for simplicity of presentation the two tables present only the result of analysis for the diets in the covered treatments in the two experiments.

\section{Experiment 1}

The results of this experiment are presented in Table 1.

TABL. 1. - Mean consistencies and regression coefficients for artificial diets based on Torula Yeast and sucrose. Means of eight recordings of three replicates of each diet in the "Covered" treatment.

(1) Difference from Common Regression Line.

\begin{tabular}{c|l|c|cr}
\hline \hline \multicolumn{1}{|c|}{ Sugar } & \multicolumn{2}{c|}{$\begin{array}{c}\text { Mean Consistency } \\
\left(\mathrm{g} / \mathrm{mm}^{2}\right)\end{array}$} & S.E. & $\begin{array}{c}\text { Regression Coefficient } \\
\text { S.E. significance (1) }\end{array}$ \\
\hline 1 & Sucrose & $10.91 \pm 1.66$ & $1.15 \pm .31$ & $\mathrm{P}<.01$ \\
2 & Sucrose + dextrose & $14.77 \pm 1.69$ & $1.24 \pm .32$ & $<.01$ \\
3 & Sucrose + glycerol & $8.89 \pm .99$ & $0.5 \pm .19$ & $<.05$ \\
4 & Sucrose + invertase & $8.92 \pm .68$ & $0.6 \pm .12$ & $\mathrm{NS}$ \\
\hline
\end{tabular}

Mean consistencies of the four diets differed significantly $(\mathrm{P}<.05)$. This difference appears to be due mainly to the diet containing sucrose and dextrose whose mean consistency was higher than the consistencies of the other three diets. Although there was no significant difference between the regression co-efficients of the four diets, the low co-efficients for diets 3 and 4 suggest that the consistencies of these diets would 
be expected to have been significantly lower that those of diets 1 and 2 if the experiment has been continued for a longer period.

Bacterial mould developed on all diets but there is no evidence that this had any effects on the consistency and rates of hardening of all diets.

\section{Experiment 2}

The results of this experiment are presented in Table 2 which shows mean consistencies and regression co-efficients for the four diets in the covered treatment.

TABL. 2. - Mean consistencies and regression coefficients of artificial protein diets based on spray dried Brewers Yeast and containing $24 \%$ Crude Protein and $25 \%$ added sugars.

Means of eight recordings of three replicates of each diet in the "Covered" treatment.

(1) Difference from Common Regression Line.

\begin{tabular}{c|l|cc|c}
\hline \hline Diet & \multicolumn{1}{|c|}{ Sugar } & $\begin{array}{c}\text { Mean Consistency } \\
\left(\mathrm{g} / \mathrm{mm}^{2}\right)\end{array}$ & \multicolumn{2}{c}{$\begin{array}{c}\text { Regression Coefficient } \\
\text { S.E. significance (1) }\end{array}$} \\
\hline 1 & Sucrose & $26.21 \pm .88$ & $1.00 \pm .16$ & $\mathrm{P}<.001$ \\
2 & Sucrose + invertase & $25.40 \pm .64$ & $1.02 \pm .12$ & $<.001$ \\
3 & Type " 50" syrup & $22.31 \pm 1.06$ & $0.60 \pm .20$ & $<.05$ \\
4 & Type " 50" + glycerol & $22.83 \pm .99$ & $0.52 \pm .19$ & $<.05$ \\
\hline \multicolumn{2}{l|}{ Probability of comparison } \\
between four diets & $\mathrm{P}<.05$ & \multicolumn{2}{c}{$\mathrm{NS}$} \\
\hline
\end{tabular}

Mean consistencies and regression co-efficients of the two diets containing the " Type 50 " syrup were lower than those of the two diets containing sucrose but overall, mean consistencies of the four diets were substantially higher than those of the diets in Experiment 1. Rates of hardening were similar in both experiments.

\section{DISCUSSION}

In both papers in this series the term " artificial protein diet " has been adopted in preference to the usual terms "pollen substitute " and "pollen supplement ". This term is more precise and avoids the confusion inherent in the indiscriminate use of the other two terms. In practice any complete artificial protein diet for honeybees would either substitute for, or supplement natural pollen according to the amounts of pollen available in the colony.

The development of mould on the diets based on Torula Yeast is attributed to the $5 \%$ mould organisms which the manufacturers' analysis showed to be present in the yeast, for no mould developed in a test mixture of heat-sterilized Torula Yeast, sucrose 
and distilled water. The mould was of bacterial origin and the addition of methyl parahydroxy benzoate to a test diet did not prevent the development of mould.

No mould developed on any diets containing spray-dried Brewers Yeast.

The physical characteristics of artificial diets are important factors influencing their acceptance by bees for they must be soft enough to enable the bees to exhibit the specific pollen feeding behaviour pattern. Bees feeding on pollen use their mandibles to scrape the pollen from the mass in the cells and to pass it back to the mouth (PARKer, 1925).

The smooth, spoon shaped mandibles of the honeybee are not adapted for chewing hard foods and so if the diets are too hard, the bees will not be able to feed on them. Even pollen that has remained in the comb may become too hard for the bees to eat and is removed from the cells and carried out of the hive by the bees (DoulL unpub. obs.).

The studies reported here do not provide any information as to the optimum range of consistency of artificial diets or of stored pollen. The consistency of stored pollen in combs taken from hives in the field was measured and was found to range between 2.5 and $5.3 \mathrm{~g} / \mathrm{mm}^{2}$. For comparison the initial consistencies of the diets tested in the experiment reported in the earlier paper and in Experiment 1 in this paper ranged between 2.5 and $8.4 \mathrm{~g} / \mathrm{mm}^{2}$, while initial consistencies of the diets tested in Experiment 2 in this paper ranger between 14.93 and $18.17 \mathrm{~g} / \mathrm{mm}^{2}$. Furthermore, a test of two diets in a hive showed that the bees consumed diets quite readily when consistencies were as high as $37 \mathrm{~g} / \mathrm{mm}^{2}$.

But this data is probably misleading for the specific pollen feeding behaviour pattern is a response by bees to specific phagostimulant chemicals in pollen (DouLL 1980).

Examination of photographic records of an earlier study (DoulL 1974) indicate that while bees feeding on artificial diets containing these phagostimulants appear to exhibit the pollen feeding behaviour pattern, bees feeding on an artificial diet that did not contain the phagostimulants usually appeared to exhibit the behaviour pattern that is typical of bees feeding on sugars. In this sugar feeding behaviour pattern the bees feed with the extended proboscis and probably use salivary secretions to dilute the food so that they can ingest it in liquid form through the proboscis (Doull 1980).

Further progress on this aspect of the formulation of artificial diets requires that test diets should contain the specific phagostimulants that are present in pollen and that elicit the specific pollen feeding behaviour pattern. The behaviour of the bees, the frequency of feeding and the length of time spent on single feeds should be recorded and this should be correlated with the consistencies of the artificial diets. 


\title{
ACKNOWLEDGEMENTS
}

The authors acknowledge technical advice from Mr. E. B. Giles and the helpful suggestions and criticisms of the two manuscripts by Dr. P. MiLes. The technical assistance of Mr. P. Mew is also acknowledged.

Received for publication in April 1980.

\author{
RÉSUMÉ \\ CARACTÉRISTIQUES PHYSIQUES DES RÉGIMES PROTÉINIQUES \\ ARTIFICIELS POUR LES ABEILLES (APIS MELLIFERA). II.
}

De nouvelles études sur les caractéristiques physiques des régimes protéiniques artificiels pour l'abeille ont examiné l'effet de différents sucres sur la consistance et les taux de durcissement des régimes. Les méthodes utilisées ont été décrites dans un premier article (Apidologie, 1980, 11, n 3, 203-208).

Dans la première expérience on a utilisé la levure Torula comme base protéinique et le saccharose comme composant glucidique. La consistance et le taux de durcissement de ce régime ont été semblables à ceux du régime renfermant du miel, qui avait été testé dans le premier article. L'addition de glycérol ou d'invertase a conduit à des réductions importantes des taux de durcissement des régimes.

La levure Torula renferme de nombreux organismes qui forment des moisissures et on n'a pas pu empêcher le développement de moisissures bactériennes à la surface et à travers l'ensemble des régimes testés par l'addition de parahydroxybenzoate de méthyle. On recommande de ne pas utiliser la levure Torula si l'analyse de fabrication montre la présence d'organismes qui produisent des moisissures.

Dans une seconde expérience, une proportion de levure de bière a été remplacée par de la caséine pour former un régime $25 \%$ C.P. - proportion existant dans le pollen. On a comparé le sirop " Type 50 nsirop inverti par une enzyme provenant des U.S.A. - avec le saccharose. Les consistances moyennes des régimes ne différaient pas, les taux de durcissement des deux régimes contenant du sirop " Type 50 " étaient significativement plus bas que ceux des régimes contenant du saccharose. Les consistances moyennes de tous les régimes étaient plus élevées que celles des régimes ne contenant pas de caséine.

La consistance des régimes artificiels est d'une grande importance, puisque les abeilles se nourrissant de ces protéines doivent être capables d'utiliser leurs mandibules pour gratter de la nourriture à la surface du régime de la même façon qu'elles se nourissent de pollen. On suggère que ce comportement est une réaction à des phagostimulants spécifiques présents dans le pollen et que les recherches futures devront identifier ces phagostimulants en étudiant le comportement alimentaire des abeilles.

\section{ZUSAMMENFASSUNG}

\author{
DIE PHYSIKALISCHEN EIGENSCHAFTEN \\ VON KÜNSTLICHER PROTEINNAHRUNG \\ DER HONIGBIENE. II.
}

In weiteren Untersuchungen über die physikalischen Eigenschaften von künstlicher Proteinnahrung für die Bienen wurde der Einfluss verschiedener Zucker auf die Konsistenz und den Anteil des Hartwerdens der Futtergemische untersucht. Die Untersuchungsmethoden wurden in der ersten Arbeit dieser Serie beschrieben.

Im ersten Experiment wurde Torulahefe als Proteinquelle und Sukrose als Zuckerkomponente benutzt. Konsistenz und Anteil von Aushärtung des Futters war ähnlich wie bei dem Futtergemisch mit 
Honig, das in der ersten Arbeit getestet worden war. Zugabe von Glycerin oder Invertase führte zu einer signifikanten Verringerung des Anteils von hart gewordenem Futter.

Die Torulahefe enthielt Organismen, die einen schimmelähnlichen Belag bildeten; die Entwicklung eines bakteriellen Belages an der Oberfläche und auch im Inneren der Versuchsmischung konnte auch durch Zugabe von Methylparahydroxybenzoat nicht verhindert werden. Es wird deshalb empfohlen, Torulahefe nicht zu benutzen, falls die Analyse der Hersteller die Anwesenheit schimmelbildender Organismen anzeigt.

In einem zweiten Experiment wurde ein bestimmter Anteil von Brauhefe durch Kasein ersetzt, um ein Futtergemisch mit $25 \%$ Rohprotein zu erhalten - also denselben Anteil wie er im Pollen gegeben ist. Der " Typ 50 " - Sirup, ein durch Enzyme invertierter Sirup aus den U.S.A. wurde mit Sukrose verglichen. Bei der mittleren Konsistenz der Futtergemische gab es keine Unterschiede, aber der Anteil des Hartwerdens war bei zwei Mischungen mit " Typ 50" - Sirup signifikant niedriger als bei einer Mischung mit Sukrose.

Die mittlere Konsistenz aller dieser Futtermischungen war höher als bei Mischungen, die kein Kasein enthielten.

Die Bedeutung der Konsistenz von künstlichen Futtermitteln muss herausgehoben werden, denn die Bienen, welche die Proteinnahrung zu sich nehmen, sollten in der Lage sein, das Futter mit ihren Mandibeln von der Oberfläche des Futterteiges abzukratzen, genauso wie beim Fressen von Pollen.

Es wird vermutet, dass dieses Verhalten eine Antwort auf eine spezifische Phagostimulans aus dem Pollen ist; künftige Forschungen sollten diese Fressstimulans identifizieren durch die Untersuchung des Fressverhaltens der Bienen.

\section{REFERENCES}

Doult K. M., 1974. - Effects of attractants and phagostimulants in pollen and pollen supplements on the feeding behaviour of honeybees in the hive. J. Apic. Res., $13: 47-52$.

Doull K. M., 1977. - Tucson pollen supplements. Am. Bee. J., 7 : 296-297.

Doull K. M., 1980. - The nutrition of honeybees. Biennal Report, Waite Agricultural Res. Inst., 1978 1979 (In press).

Doull K. M., Hancock T. and Standifer L. N., 1980. - The physical characteristics of artificial protein diets for honeybees. Apis mellifera. L. I (In press).

Herbert E. W., Shimanuki H. and Caron D., 1977. - Caged honeybees (Hymenoptera Apidae); Comparative value of some proteins for intiating and maintaining broodrearing. Apidologie, 8 : 229-235.

KLeinschmidt G. J. and Kondos A. C., 1976. - The influence of crude protein levels on colony produc tion. Aust. Beekeeper., $78: 36-39$.

PARKer R. L., 1926. - The collection and utilization of pollen by the honeybee. Cornell. Uni Ag. Exp. Sta. Memoir No. 98.

Standifer L. N., Moeller F. E., Kauffeld N. M., Herbert E. W. Jr and Shimanuki H., 1978. - Supplementary feeding of honeybee colonies. U.S.D.A. Agr. Inf. Bull. 413. 